\title{
ANCAMAN ERUPSI KAWAH IJEN TERHADAP MASYARAKAT LERENG IJEN (KABUPATEN BONDOWOSO)
}

\author{
Dhimas Bagus Virgiawan \\ Dosen Jurusan Tadris Ilmu Pengetahuan Sosial, Fakultas Tarbiyah dan Ilmu Keguruan, Institut \\ Agama Islam Negeri Ponorogo, Jl. Pramuka 156, PO. Box 116 Ponorogo 63471, \\ dhimasbagusvirgiawan@gmail.com
}

\begin{abstract}
ABSTRAK
Kompleks Kaldera Ijen merupakan kompleks gunung api yang mempunyai kaldera berdiameter sekitar $15-16 \mathrm{~km}$ berbentuk elips yang hanya menyisakan dinding kaldera bagian utara melengkung ke arah selatan. Kawah Ijen sebagai gunung api termuda dan masih aktif hingga saat ini secara stratigrafi tersusun atas aliran lava, endapan aliran piroklastika, dan jatuhan piroklastika. Ancaman yang muncul jika terjadi erupsi adalah aliran piroklastika, jatuhan piroklastika, aliran lava, aliran lahar, dan air kawah Ijen. Keberadaan aktifitas vulkanik kawah Ijen berdapamk positif terhadap masyarakat yang tinggal di sekitar kawasan gunung Ijen. Perekonomian mereka bertumpu pada hasil menambang belerang serta kesuburan tanah yang dimanfaatkan untuk budidaya tanaman kentang, kubis, kopi. Bila hal ini terjadi dapat merupakan ancaman serius bagi lingkungan sekitarnya, termasuk penduduk yang bermukim di sekitar gunung api dan di sepanjang sungai yang berhulu di danau kawah ini dan merupakan malapetaka. Bencana dapat sangat besar karena volume air danau kawah yang cukup besar dan sangat asam, di samping hasil letusan seperti awan panas, erupsi freatik berupa lahar letusan juga mungkin terjadi.
\end{abstract}

Kata kunci: karakteristik, erupsi, gunung ijen

\section{ABSTRACT}

Ijen caldera complex is a volcano that has a $7 \mathrm{~km}$ diameter elliptical caldera which only leaving a northern caldera wall curving towards the southward. Ijen crater as a youngest volcano and still active today stratigraphically composed of lava flow, pyroclastic flow sediments, and pyroclastic fallout. Threats that arise if an eruption occur is pyroclastic flow, pyroclastic fallout, lava flow, lahar flow, and water of ijen crater. The existance of vulcanic activity of Ijen crater impact positively to the society which live around the Ijen mountain region. Their economy rest on sulphur mining and the soil fertility which is used to potato, cabbage and coffee crop cultivation. If this happen it could be a serious threat for the environment, include the population settled around volcano and along the river upstream in the lake of this crater and is a catastrophe. The disaster can be huge because water volume of large enough crater lake and very acidic, besides the result of explotion such as hot clouds, phreatic eruption in the form of lava eruption is also possible to happen.

Keywords: characteristic, eruption, ijen mountain

\section{PENDAHULUAN}

Kawasan gunung api di Indonesia merupakan daerah pertanian yang subur dan selalu padat penduduk sejak zaman dahulu, walaupun tidak lepas dari ancaman bencana letusan. Dalam rekaman sejarah gunung api di dunia, tercatat sepuluh letusan besar yang menelan korban lebih dari 211.000 jiwa, dua di antaranya terjadi di Indonesia, yaitu Gunung Tambora tahun 1815 (lebih dari 80.000 jiwa), dan Gunung Krakatau tahun 1883 (36.000 jiwa). 
Berdasarkan catatan Pusat Vulkanologi dan Mitigasi Bencana Geologi ${ }^{1}$, gunung api aktif di Indonesia terbagi dalam tiga kelompok berdasarkan sejarah letusannya, yaitu tipe A (79 buah), adalah gunung api yang pernah meletus sejak tahun 1600, tipe B (29 buah) adalah yang diketahui pernah meletus sebelum tahun 1600 dan tipe C (21 buah) adalah lapangan solfatara dan fumarola ${ }^{2}$.

Indonesia merupakan salah satu negara dengan sebaran gunung api yang banyak. Ada sekitar 129 gunung api di Indonesia atau 13\% yang ada di dunia. Hal ini terjadi karena Indonesia berada pada daerah pertemuan lempeng tektonik yaitu lempeng Eurasia, lempeng Indo Australia dan lempeng Pasifik. Salah satu gunung api yang terkenal adalah Gunung Ijen yang terletak di Kabupaten Banyuwangi dengan koordinat $8^{\circ} 03,5^{\text {ece }} \mathrm{LS}$ dan $114^{\circ} 14,5^{\text {ce }} \mathrm{BT}$. Gunung Ijen merupakan gunung api stratovolcano yaitu gunung api yang tinggi dan mengerucut. Gunung Ijen dicirikan dengan danau kawah yang berukuran \pm 960 x 600 meter dengan kedalaman air danau \pm 200 meter yang dibatasi oleh pematang kawah berketinggian antara 2145 sampai 2386 m d.p.l. Gunung Ijen ini pernah meletus pada tahun 1796, 1817, 1917, 1936, 1952, 1962, 1976, 1991, 1993, 1999, 2000, 2001, 20044, 2005.

Keunikan Kompleks Gunung Ijen dibandingkan dengan gunung api lainnya di Indonesia adalah sebagai model perpaduan antara pertumbuhan gunung api poligenetik dan monogentik yang tumbuh di dalam dan di pinggir kaldera. Pada umumnya aktivitas gunung api pasca pembentukan kaldera membentuk kompleks gunung api monogenetic tetapi pada gunung api yang berukuran besar membentuk gunung api poligenetik yang umumnya tumbuh pada dinding kaldera.

Keunikan lainnya dari Kompleks Gunung Ijen adalah gunung api yang mempunyai danau kawah dengan kedalaman sekitar $190 \mathrm{~m}$ dan mempunyai derajat keasaman yang sangat tinggi $(\mathrm{pH}<0,2)$ serta volume air danau yang sangat besar, sekitar 36 juta m3. Sejarah pembentukan gunung api ini pada masa lampau menjadikan Kawah Ijen memiliki potensi untuk menghasilkan lahar letusan, selain potensi ancaman bahaya erupsi lainnya. Jumlah populasi yang cukup padat di kawasan rawan bencana gunung api dan jumlah wisatawan yang cukup banyak menimbulkan permasalahan yang sangat penting dalam mitigasi bencana Gunung Ijen

\footnotetext{
${ }^{1}$ Pusat Vulkanologi dan Mitigasi Bencana Geologi. http://www.vsi.esdm.go.id. (online) diakses pada tanggal 2 Mei 2017.

2 Kusumadinata, K., Hadian, R., Hamidi, S., dan Reksowirogo, L., D., 1979, Data Dasar Gunung api Indonesia, Direktorat Vulkanologi, Direktorat Jenderal Geologi dan Sumberdaya Mineral, Departemen Pertambangan dan Energi, RI.
} 


\section{HASIL DAN PEMBAHASAN \\ Geologi Kompleks Gunung Ijen}

Kompleks Kaldera Ijen merupakan kompleks gunung api yang mempunyai kaldera berdiameter sekitar 15 - $16 \mathrm{~km}$ berbentuk elips yang hanya menyisakan dinding kaldera bagian utara melengkung ke arah selatan. Dinding kaldera selatan sebagian besar telah tertutupi oleh endapan vulkanik hasil erupsi kerucutkerucut gunung api yang aktif pasca kaldera. Gunung Kendeng merupakan gunung api tunggal dan besar dengan ketinggian sekitar $4.000 \mathrm{~m}$ dpl, karena suatu letusan paroksisma mengakibatkan bagian puncaknya hilang. Berdasarkan umur mutlak dan umur relative dari beberapa endapan batuan yang terdapat di wilayah ini, kompleks Kaldera Ijen dapat dibagi menjadi tiga fase pembentukan gunung api sesuai dengan tahap kegiatan vulkanismenya, yaitu: fase Gunung Ijen Tua (Gunung Kendeng), fase non vulkanisme dengan terbentuknya Danau Blawan, dan fase vulkanisme pasca Kaldera Ijen ${ }^{3}$.

Gunung Kendeng merupakan gunung api strato terbentuk pada zaman Plistosen ${ }^{4}$. Aktivitas gunung api ini berakhir setelah terbentuk kaldera pada kisaran waktu antara 300.000-50.000 tahun yang lalu, menghasilkan endapan aliran piroklastika (ignimbrit) dan jatuhan piroklastika. Endapan batuan ini tersebar sangat luas menutupi hamper seluruh permukaan gunung api tersebut dengan ketebalan lebih dari $50 \mathrm{~m}$ di sekitar dinding dan dasar kaldera serta lebih dari $15 \mathrm{~m}$ di sekitar dam Liwung, Asembagus. Dalam pencapaian keseimbangan setelah terbentuknya kaldera terbentuklah sesar Pedati di dinding kaldera utara dan sesar Jampit di dinding kaldera barat daya.

Aktivitas vulkanik pertama yang terjadi pasca kaldera tidak dapat diketahui secara pasti, tetapi berdasarkan umur endapan batuan yang telah dilakukan, pentarikhannya adalah sebagai berikut: Gunung Blau berumur sekitar 50.000 tahun, kemudian disusul oleh aktivitas Gunung Jampit yang berumur sekitar 45.000 tahun, atau kedua gunung api tersebut bererupsi pada kurun waktu yang hampir bersamaan. Setelah aktivitas kedua gunung api tersebut kemudian muncul Gunung Suket di dinding kaldera barat laut berumur 37.900 tahun yang umurnya hampir bersamaan dengan Gunung Rante di dinding kaldera selatan (30.000 tahun), Gunung Ringgih di dinding kaldera timur laut (29.800 tahun), dan Gunung Pawenan di dinding timur ( 24.400 tahun). Bila melihat lokasinya Gunung Blau dan Gunung Jampit terletak pada sesarsesar yang terbentuk dalam generasi pertama setelah terbentuknya kaldera, kemudian disusul aktivitas-aktivitas gunung api yang muncul di dinding kaldera seperti Gunung Suket, Gunung Ringgih, Gunung Pawenan, Gunung Merapi, dan Gunung Rante.

Generasi berikutnya adalah gunung-gunung api yang muncul berarah timur - barat, seperti Gunung Papak, Gunung Kukusan, Gunung Widodaren, Gunung Gending Waluh, Gunung Malang, Gunung Anyar, Gunung Ijen, dan sebagainya. Kerucut-kerucut tersebut relative lebih kecil dari gunung api yang muncul di dinding kaldera. Gunung Ijen merupakan gunung api yang saat ini masih aktif. Gunung api ini membangun tubuhnya sekitar 6.000 tahun yang lalu berdasarkan penanggalan umur dari arang yang terdapat dalam endapan aliran abu.

\footnotetext{
3 Zaennudin, A., Sumarti S., Sutaningsih, E.N., dan Sukarnen, 2005, Genetic of an Ancient Lake Blawan, Ijen Caldera, East Java, Annual Meeting of Geological Association of Indonesia, Surabaya - Indonesia

${ }^{4}$ Buranda, J.P. 2013. Bahan Ajar Geologi Indonesia. IKIP Malang
} 


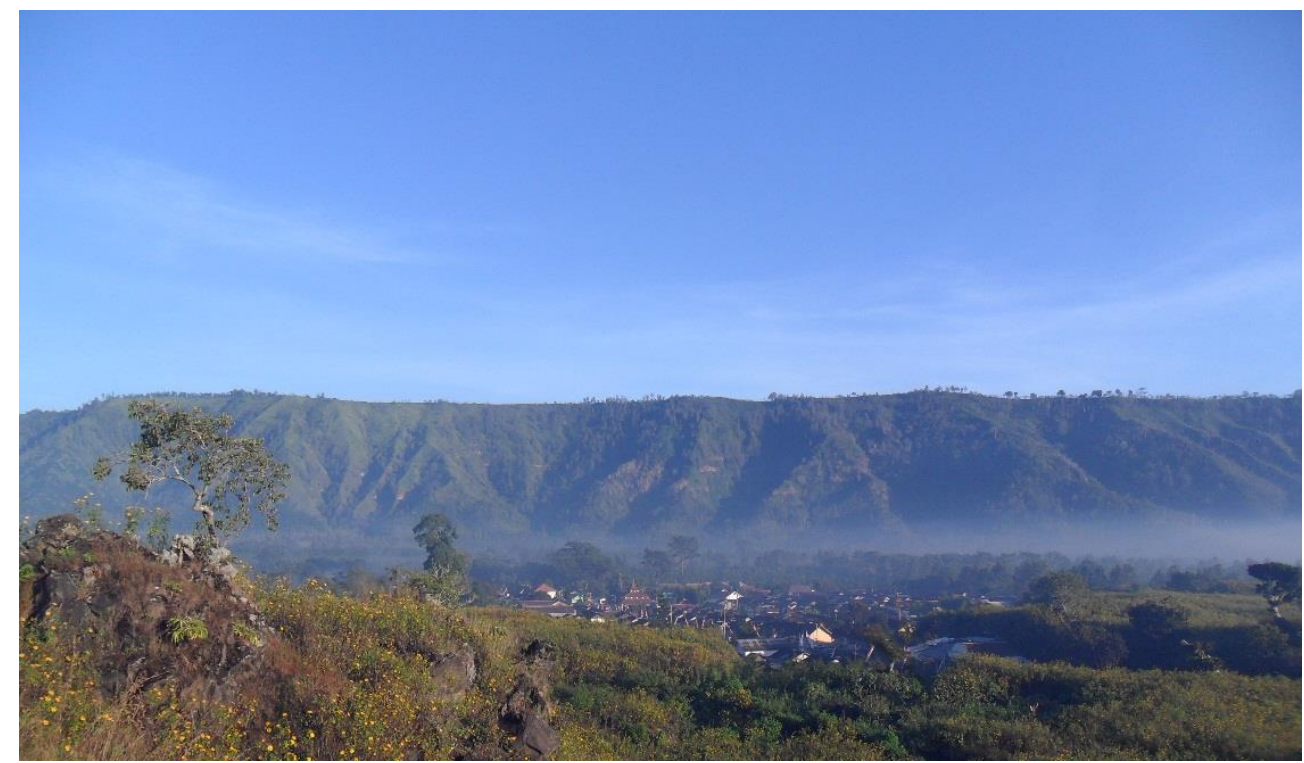

Gambar 1. Dinding Kaldera Ijen bagian barat yang masih dapat dikenali Sumber: Dokumentasi Pribadi

\section{Geomorfologi Kompleks Gunung Ijen}

Kompleks Gunung Ijen merupakan model pertumbuhan gunung api poligenetik (stratovolcano) dan monogenetik yang terbentuk di dasar dan dinding kaldera, pasca pembentukan kaldera. Sebagian kerucut gunung api strato tumbuh di dasar kaldera dan sebagian besar lainnya tumbuh di pinggir kaldera sehingga mengakibatkan hanya sebagian dinding Kaldera Ijen yang terlihat masih utuh (Gambar 1).

Berdasarkan urutan arah jarum jam, kerucut gunung api strato di Kompleks Gunung Ijen adalah Gunung Kukusan, Gunung Merapi, Gunung Rante, Gunung Pendil - Jampit, dan Gunung Suket. Sementara itu, kerucut gunung api strato yang tumbuh di dasar kaldera, yaitu

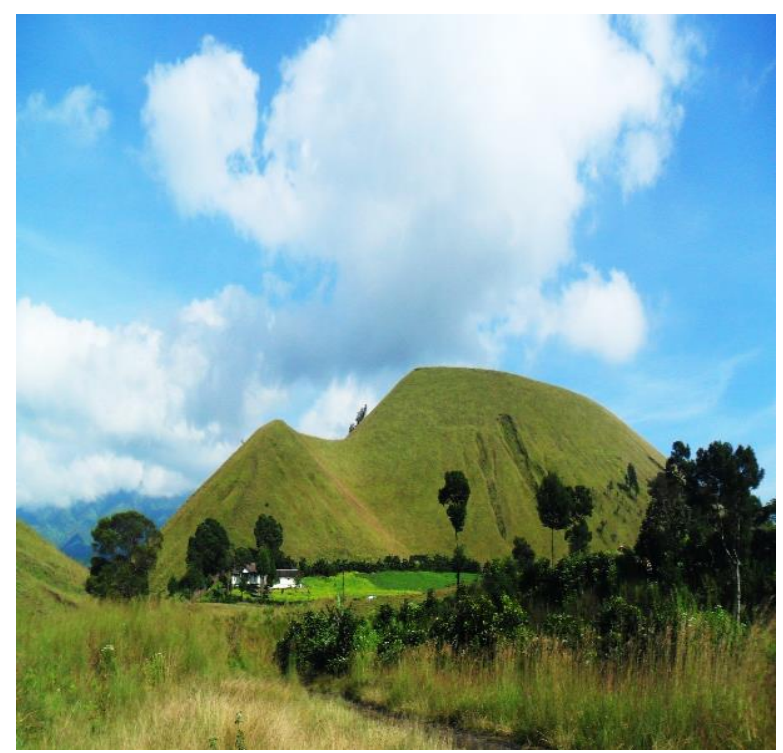

Gambar 2. Kerucut Sinder yang terdapat di Afdeling Jampit kabupaten Bondowoso

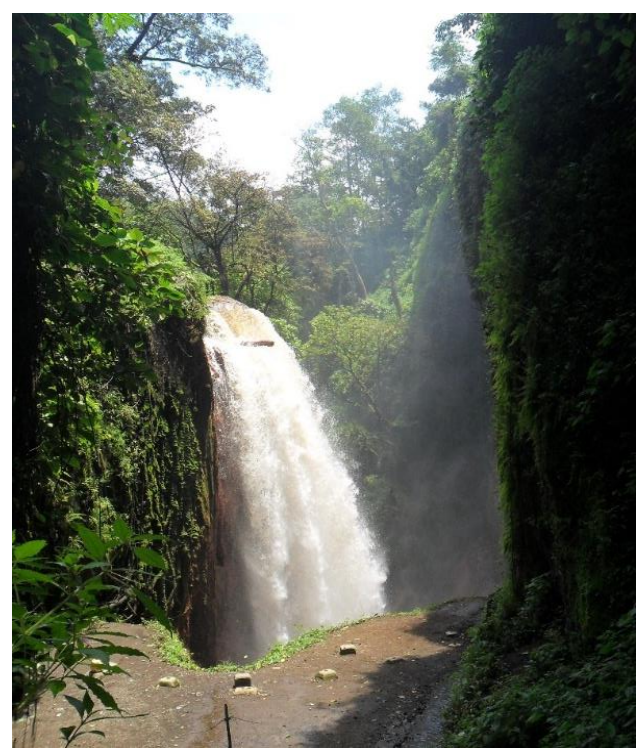

Gambar 3.Celah sempit sekitar Balawan yang diduga terbentuk oleh proses tektonik yang membelah dinding Kaldera Ijen bagian utara.

Sumber: Dokumentasi Pribadi 
Gunung Blau, Gunung Pawenan, dan Gunung Ijen sebagai kerucut gunung api termuda, berada di bagian timur laut Kaldera Ijen. Berdasarkan dimensi tubuh gunung api nya, kerucut gunung api strato yang tumbuh di bagian pinggir kaldera lebih besar diban dingkan dengan yang tumbuh di dasarnya. Pola lerengtubuh gunung api ini yang cende rung berkembang ke arah luar kaldera mencerminkan distribusi bahan letusan gunung api menjauhi kaldera. Hal ini diinterpretasikan bahwa pertumbuhan kerucut gunung api strato ini berada di dinding luar kaldera.

Sedikitnya terdapat 17 kerucut sinder sebagai gunung api monogenetik yang terkonsentrasi di dasar Kaldera Ijen (Gambar 2). Dimensi tubuh kerucut sinder yang bervariasi menunjukkan variasi fase erupsinya. Secara umum, dimensi tubuh kerucut sinder di Kompleks Gunung Ijen dikelompokan ke dalam dimensi kerucut besar dan kecil. Kerucut sinder berdimensi besar, seperti Kukusan, Genteng, dan Jampit, berbentuk agak memanjang dengan ketinggian rata rata $100 \mathrm{~m}$ dari bagian dasar dan panjang lereng bawah mencapai $2-5 \mathrm{~km}$. Pada umumnya, tipe kerucut sinder ini memiliki fase erupsi yang lebih panjang dengan variasi material letusan berupa jatuhan piroklastika dan aliran lava. Sementara itu, kerucut sinder dengan dimensi kecil, seperti Gending Waluh, Anyar, Lingkar, dan Melatan, memiliki rata - rata ketinggian dan diameter $50 \mathrm{~m}$ dan $500 \mathrm{~m}$. Produk letusan pada umumnya hanya jatuhan piroklastika yang kemungkinan terbentuk melalui satu fase letusan dalam urun waktu yang tidak terlalu lama.

Pola sebaran kerucut sinder dan lerengnya di antara kerucut di dasar kaldera menghasilkan morfologi perbukitan rendah bergelombang. Kondisi ini menyebabkan jarangnya dijumpai lembah sungai permanen, kecuali Kali Banyupait dan Kali Sengon yang berhulu di lereng atas Kawah Ijen. Kedua sungai ini mengalir ke arah utara kaldera dan keluar kaldera melalui celah sempit (Gambar 3), di sekitar kampung Balawan, yang diduga terbentuk karena proses tektonik.

\section{Vulkanisme Kompleks Gunung Ijen}

Vulkanisme Gunung Ijen Tua (Gunung Kendeng) berlangsung kira - kira selama 400.000 tahun dengan asumsi awal vulkanisme sekitar 700.000 tahun yang lalu berdasarkan studi regional. Fase vulkanisme ini berasal dari diferensiasi magma yang manghasilkan produk erupsi berupa aliran lava dan endapan piroklastika berkomposisi basaltik hingga dasitik ${ }^{5}$. Endapan aliranpiroklastika dan jatuhan piroklastika secara dominan tersusun oleh batu apung dan sebagian litik andesit dan basalt. Aliran lava berkomposisi sangat variatif mulai dari basalt, andesit hingga dasit. Berdasarkan variasi komposisi kimia batuannya, vulkanisme Ijen Tua berlangsung secara dinamis dalam kurun waktu yang diduga cukup panjang.

Setelah vulkanisme berlangsung selama kurang lebih 400.000 tahun, erupsi berskala sangat besar yang identik dengan tipe letusan plinian yang terjadi antara 300.000-50.000 tahun yang lalu, menghasilkan kaldera dengan diameter $14-16 \mathrm{~km}$. Pembentukan kaldera tersebut disertai dengan pembentuk an endapan aliran piroklastika berbatuapung yang tersebar ke bagian lereng utara dari sumber erupsi.

\footnotetext{
${ }^{5}$ Sujanto, Syarifudin, M.Z., dan Sitorus, K., 1988, Peta Geologi Gunung api Komplek Kaldera ljen, Jawa Timur. Bandung: Direktorat Vulkanologi.
} 
Vulkanisme lanjutan pasca pembentukan kaldera berlangsung sekitar 50.000 tahun yang lalu, terjadi di dasar dan dinding kaldera. Vulkanisme lanjutan ini dapat dikelompokan kedalam 2 tipe, yaitu monogenetik dan poligenetik yang tumbuh secara simultan. Sebagian besar gunung api poligenetik, seperti Ringgih - Kukusan, Merapi, Rante, Jampit - Pendil, dan Suket, tumbuh pada bagian dinding kaldera. Sementara itu 3 gunung api poligenetikBlau, Pawenan, dan Kawah Ijen, tumbuh di dasar kaldera membentuk kelompok yang terpisah dari 12 buah gunung api monogenetik. Kelompok gunung api poligenetik menghasilkan variasi produk letusan yang terdiri atas aliran lava, aliran piroklastika, dan jatuhan piroklastika berkomposisi basaltik hingga andesitik. Sementara itu, gunung api monogenetik membentuk kerucut sinder dengan aliran lava berkomposisi basaltik dan andesit basaltik. Kerucut sinder berdimensi besar,

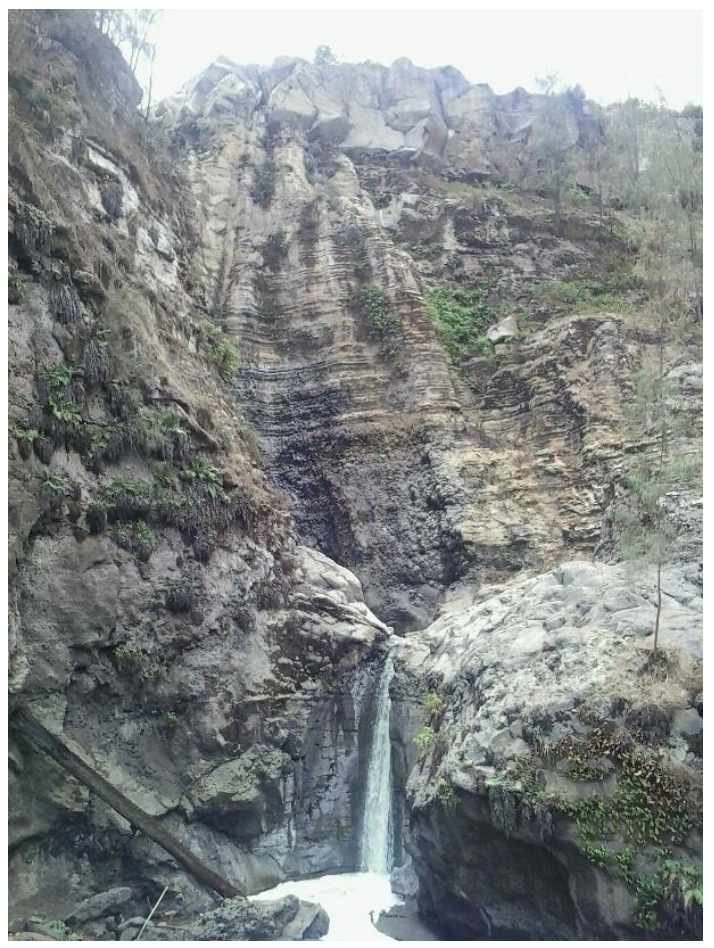

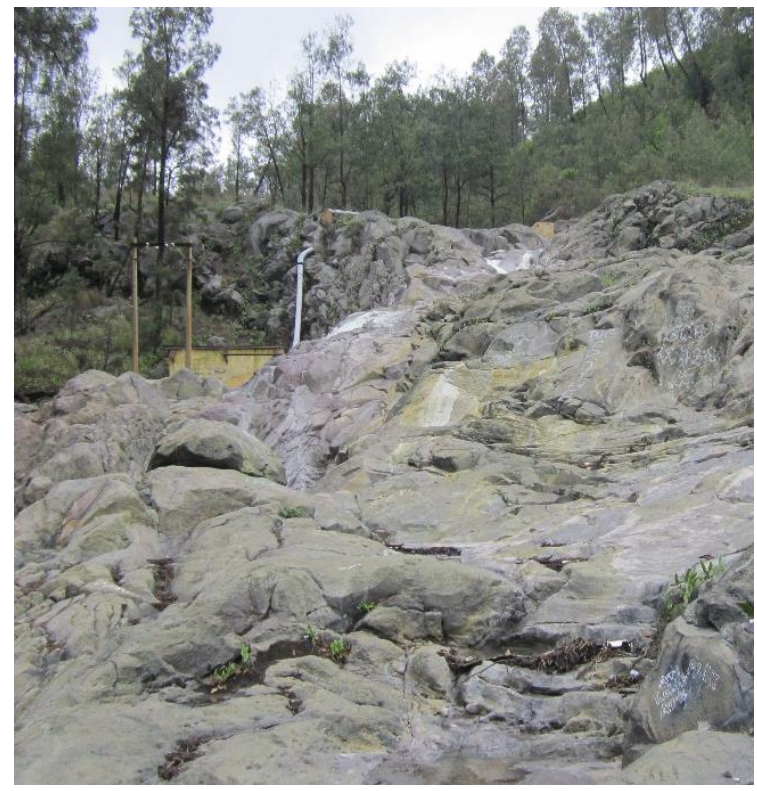

Gambar 5. Kompleks batuan beku hasil erupsi gunung Ijen

Sumber: Dokumentasi Pribadi

Gambar 4. Endapan aliran piroklastik hasil pembentukan erupsi gunung Ijen

Sumber: Dokumentasi Pribadi

seperti Kukusan, Genteng, dan Jampit. Pada umumnya memiliki fase erupsi yang lebih panjang dengan variasi material letusan berupa jatuhan piroklastika dan aliran lava (Gambar 4 dan Gambar 5). Sementara itu, kerucut sinder dengan dimensi kecil, seperti Gending Waluh, Anyar, Lingkar, dan Melatan, pada umumnya hanya tersusun atas jatuhan piroklastika yang kemungkinan terbentuk melalui satu fase letusan dalam kurun waktu yang tidak terlalu lama.

Kawah Ijen sebagai gunung api termuda dan masih aktif hingga saat ini secara stratigrafi tersusun atas aliran lava, endapan aliran piroklastika, dan jatuhan piroklastika. Letusan freatik memiliki potensi besar terjadi di Kawah Ijen, sehubungan dengan kondisi kawah yang terisi air. Danau Kawah Ijen ini memiliki derajat keasaman yang sangat tinggi dengan pH 0,2 yang disebabkan adanya interaksi antara air dan gas magma ${ }^{6}$ (Sumarti, 1998). Fumarola dengan kan

\footnotetext{
${ }^{6}$ Sumarti, S., 1998, Volcanogenic Pollutants in Hyperacid River Discharge from Ijen Crater Lake, East Java, Indonesia, Thesis of Doctorandus- Degree in Geochemistry, Faculty of Earth Sciences, Utrecht University.
} 
dungan $\mathrm{SO}$, $\mathrm{HCl}, \mathrm{HF}$, dan lain sebagiannya menghasilkan kandungan sulfat, klorida, dan fluorida yang sangat pekat pada air danau kawah.

\section{Ancaman Erupsi Gunung Ijen}

Gunung Ijen memiliki sebuah kaldera yang terisi air dengan sifat sangat asam. Kondisi demikian mengakibatkan terdapat banyak ancaman jika terjadi erupsi. Berikut:

- Aliran Piroklastika

Pelemparan aliran piroklastika Kawah Ijen memiliki potensi kuat untuk melanda Banyupahit, celah antara kerucut Blawa dan Pawenan, celah antara Pawenan dan gunung Merapi, dan Kali Bendo sebagai lembah antara gunung Rante dan tubuh gunung Merapi.

- Jatuhan Piroklastika

Prakiraan bahaya jatuhan piroklastika dapat dikelompokkan menjadi hujan abu dan lontaran batu pijar. Kedua produk erupsi gunungapi ini terbentuk melalui mekanisme dan waktu yang sama. Pergerakan dan sebaran abu vulkanik sangat dipengaruhi oleh arah dan kecepatan angin, sedangkan lontaran batu (pijar) tidak dipengaruhi angin sehubungan berat batuannya. Erupsi gunungapi Komplek Ijen pada masa prasejarah kehidupan manusia sering kali menghasilkan lontaran batu dan hujan abu lebat. Identifikasi singkapan lontaran batu yang berasal dari erupsi prasejarah banyak dijumpai di lereng barat dan kawasan puncak.

- Aliran Lava

Aliran lava Komplek Ijen terbentuk selama prasejarah dengan jarak pelamparan berkisar antara $5 \mathrm{~km}$ - hampir $17 \mathrm{~km}$ dari sumber erupsi. Kawah Ijen menghasilkan aliran lava dengan jangkauan antara 4-15 km. Aliran lava prasejarah Kawah Ijen berkomposisi basaltis. Sehubungan dengan viskositasnya yang encer, pelamparan aliran lava dapat mencapai jarak beberapa kilometer dari sumber erupsinya. Meskipun demikian, pengalirannya dikontrol oleh kondisi morfologi.

Prakiraan ancaman bahaya aliran lava dari Kawah Ijen pada erupsi yang akan datang didasarkan atas perpaduan data deterministik dan simulasi dengan parameter aliran lava basaltis yang diadopsi dari beberapa sumber pustaka dan kondisi morfologi di Komplek Ijen. Prakiraan bahaya aliran lava mengarah ke utara melalui Kali Banyupahit dan Kali Senon dan berhenti mendekati celah kaldera di sekitar Blawan. Jarak pelamparan aliran lava ini mendekati $13 \mathrm{~km}$. Sementara itu, kecenderungan aliran lava ke arah selatan melalui Kali Bendo dapat mencapai kira - kira mendekati 9 km dari sumber erupsi.

- Aliran Lahar

Lahar hujan di gunungapi Komplek Ijen kemungkinan terjadi setelah terjadi erupsi berdasarkan data deterministik geologi pada masa lampau. Material potensi lahar yang berasal dari endapan aliran piroklastika dan abu letusan memiliki potensi untuk menjadi lahar melalui Kali Banyupait dan Kali Sengon. Sementara itu, material potensi lahar yang berasal dari abu letusan memiliki potensi untuk menjadi lahar melalui sungai - sungai yang berpola radial yang berhulu di kawasan puncak.

- Air Kawah Ijen

Ancaman bahaya yang berasal dari Kawah Ijen selain material hasil erupsi gunungapi adalah air danau kawah dengan derajat keasaman yang sangat tinggi ( $\mathrm{pH} 0.2)$. Kondisi keasaman air danau (hyper-acid water) disebabkan adanya interaksi antara air dan gas magma (Sumarti, 
1998). Fumarola dengan kandungan $\mathrm{SO} 2, \mathrm{HCl}, \mathrm{HF}$, dan lain sebagianya menghasilkan kandungan sulfat klorida dan fluorida yang sangat pekat pada air danau kawah. Hasil simulasi memperlihatkan bahwa aliran lahar letusan apabila diarahkan ke utara melalui Kali Banyupait dan Kali Sengon mencapai jarak sekitar $23 \mathrm{~km}$ dari sumber erupsi. Sementara itu, apabila simulasi diarahkan ke selatan melalui Kali Bendo dapat mecapai jarak

$27 \mathrm{~km}^{7}$.

\section{PENUTUP}

Tipe gunung api Ijen adalah kerucut gunung api strato yang tumbuh pada tepi Kaldera Ijen bagian tenggara yang mempunyai danau kawah di puncaknya. Danau kawah ini terisi air yang sangat asam bervolume sekitar $36.000 .000 \mathrm{~m} 3$. Gunung api ini dalam pembentukan tubuhnya pernah terjadi letusan-letusan eksplosif yang hebat dengan jejaknya berupa kawah berdiameter 600 x $900 \mathrm{~m}$. Letusan abad ke-19 merupakan letusan freatik terbesar yang tercatat dalam sejarah. Air danau tumpah ke arah utara sampai mencapai Asembagus dan ke arah tenggara mencapai Rogojampi. Sejarah geologi Gunung Ijen maupun Gunung Kendeng (Gunung Ijen Tua) menunjukkan sering meletus hebat, maka tidak menutup kemungkinan pada masa mendatang dapat meletus dengan hebat seperti yang pernah terjadi sebelumnya. Bila hal ini terjadi dapat merupakan ancaman serius bagi lingkungan sekitarnya, termasuk penduduk yang bermukim di sekitar gunung api dan di sepanjang sungai yang berhulu di danau kawah ini dan merupakan malapetaka. Bencana dapat sangat besar karena volume air danau kawah yang cukup besar dan sangat asam, di samping hasil letusan seperti awan panas, erupsi freatik berupa lahar letusan juga mungkin terjadi.

\section{DAFTAR PUSTAKA}

Buranda, J.P. 2013. Bahan Ajar Geologi Indonesia. IKIP Malang

Kusumadinata, K., Hadian, R., Hamidi, S., dan Reksowirogo, L., D., 1979, Data Dasar Gunung api Indonesia, Direktorat Vulkanologi, Direktorat Jenderal Geologi dan Sumberdaya Mineral, Departemen Pertambangan dan Energi, RI.

Pusat Vulkanologi dan Mitigasi Bencana Geologi. http://www.vsi.esdm.go.id. (online) diakses pada tanggal 2 Mei 2017.

Sujanto, Syarifudin, M.Z., dan Sitorus, K., 1988, Peta Geologi Gunung api Komplek Kaldera Ijen, Jawa Timur. Bandung: Direktorat Vulkanologi.

Sumarti, S., 1998, Volcanogenic Pollutants in Hyperacid River Discharge from Ijen Crater Lake, East Java, Indonesia, Thesis of Doctorandus- Degree in Geochemistry, Faculty of Earth Sciences, Utrecht University.

\footnotetext{
${ }^{7}$ Zaenunudin, A., Deden W., Mamay S., dan Kusdinar. 2012. Prakiraan Bahaya Letusan Gunung Api Ijen Jawa Timur. Jurnal Lingkungan dan Bencana Geologi, Vol. 3 No. 2 Agustus 2012: 109132. Bandung
} 
Zaenunudin, A., Deden W., Mamay S., dan Kusdinar. 2012. Prakiraan Bahaya Letusan Gunung Api Ijen Jawa Timur. Jurnal Lingkungan dan Bencana Geologi, Vol. 3 No. 2 Agustus 2012: 109-132. Bandung

Zaennudin, A., Sumarti S., Sutaningsih, E.N., dan Sukarnen, 2005, Genetic of an Ancient Lake Blawan, Ijen Caldera, East Java, Annual Meeting of Geological Association of Indonesia, Surabaya - Indonesia 